\title{
Multicriteria 3PL Selection with Risk Considerations
}

\author{
J.C. Osorio ${ }^{1}$, D.F. Manotas ${ }^{1}$, J.L. García ${ }^{2}$ \\ ${ }^{1}$ Universidad del Valle, Escuela de Ingeniería Industrial, Cali, \\ Colombia \\ ${ }^{2}$ Universidad Autónoma de Ciudad Juárez, \\ Departamento de Ingeniería Industrial y Manufactura, \\ Mexico \\ \{juan.osorio,diego.manotas\}@ correounivalle.edu.co,jorge.garcia@uacj.mx
}

\begin{abstract}
Supplier selection is a critical activity for organizations, because it directly affects their performance and affects the productivity and competitiveness of the firm. It has been widely accepted in academic literature that this problem has a clear strategic nature multi definition. Third Party Logistics Providers (3PL) have been widely promoted by the phenomenon of outsourcing, on which companies increasingly rely. On the other hand, risk management in supply chains (SCRM, Supply Chain Risk Management) is one of the issues that are gaining more strength today. We propose a multicriteria approach using fuzzy analytic Hierarchy Process with TOPSIS for the 3PL supplier selection with risk considerations. The model was validated for a real case in Colombia.
\end{abstract}

Keywords: Multicriteria approach, supplier selection, third party logistics, supply chain risk management, fuzzy AHP, topsis.

\section{Introduction}

Supplier selection (SS) has received considerable attention for its significant effect toward successful Logistic and supply chain management (LSCM) [2]. It is a strategic and long-term decision. A long term relationship with suppliers is greatly beneficial to the buyer, and offers advantages such as stability in future plans and strategies, reliability of product quality and service time, better understanding of the supply chain, potential discounts, and superior inventory utilization [7].

Choosing suppliers should not solely depend on their eligibility at the time of the decision-making. It is essential to predict and analyze the past changes and future potentials of suppliers, as it lowers the need to periodically assess and replace existing contracts. The overall market condition has distinctive effects and consequences on different suppliers, and so it is important to assess the relationships of suppliers and their relative changes throughout time, to assure an optimized supply chain [7].

Supply relationship management in supply chains seeks the participation of good suppliers providing low cost and high quality. A recent trend in 21 st Century business is outsourcing product manufacturing. With an increase in outsourcing, offshoresourcing, and electronic business, supply management decisions are becoming 
evermore complex in a global market. Supply management strategies such as off-shoresourcing can emphasize manufacturers at low cost locations such as China, India, or Vietnam, assemblers at hightech operations in Taiwan and Korea, and distributors where customers reside all over the globe. There are increased risks expected from differences in product quality, as well as differences in the probabilities of late delivery [28].

The supplier selection decision in a supply chain does not depend solely on cost or quality measures, but also on various risk and socio-economic factors, usually incorporated as constraints or filters. Many supply chain risks have been identified. Various risks can be the major factors that influence the supplier selection [28].

Vendor selection is of prime importance in the enterprise supply chain management. Modern trend of purchasing management is to reduce the number of vendors, and establish the long-term and stable partnership of mutual trust, benefit and support. These trends aggravate the risk of vendor selection. So enterprises in selecting vendors should measure all aspects of the performance of candidate vendors, not only the product quality, price, vendor performance and services, but also the risk factors of vendor selection [19].

Every supply chain is composed of a network of businesses where each depends on upstream business for supplies and services. A reliability chain exists along supply chains. The reliability of one company in a supply chain depends on the reliability of its predecessor. The reliability of that predecessor depends on the reliability of its own predecessor along the supply chain and so on [16].

The increasing need of the companies to focus on the core business object has generated a trend oriented to outsource different activities. In this context, supply chain activities have evolved from a first stage where we have companies that are responsible for their logistics processes up to the current trend with companies who have delegated all their logistics activities to specialized agents. (Osorio et al, 2015)

Table 1 presents the principals and recent works and technics used by the authors in the multicriteria supplier selection problem. The authors have been used combinations and hybrids tools.

We can mention these papers about multi criteria 3PL selection processes: [18] using fuzzy Delphi, fuzzy inference and fuzzy linear programming. They don't present the risk like explicit criteria but consider 26 criteria and risk is implicit in many of them. [17] using fuzzy sets and they don't include risk like criterion. [8] present a model that integrates case-based reasoning, rule-based reasoning and compromise programming techniques in fuzzy environment. Although risks are not explicit in the model, they are considered in the decision. Finally, [6] present an integrated fuzzy QFD and fuzzy AHP. In this case, risk is an explicit criterion.

\section{Methodology}

We proposed a FAHP integrated with TOPSIS methodology. We obtained the weight of criteria with the FAHP and then apply TOPSIS methodology to 3PL supplier selection according with the criteria. The needs are represented on the weights that Organization experts assigned to each criterion by applying the methodology FAHP. 
For the weighting of the criteria It was used a classical Saaty scale but with triangular fuzzy numbers (Table 2). And with the results of the analysis will continue with the implementation of the TOPSIS methodology.

The first step is to define the decision criteria. There are in the literature a lot of criteria, qualitative and quantitative that depends heavily on the organization and its supplier's policies. This methodology was validated in a Colombian company (Urbano y Muñoz, 2013).

Table 1. Principal papers about multi criteria supplier selection with risk considerations.

\begin{tabular}{ll}
\hline Approach & Articles \\
\hline FMCDM (Fuzzy Multicriteria Decision Making) & {$[10][9]$} \\
AHP and Entropy & {$[1]$} \\
Grey Relational Analysis & {$[26][23]$} \\
AHP & {$[13][16][15][14]$} \\
Fuzzy TOPSIS & {$[21][24]$} \\
FAHP & {$[14][3][12]$} \\
Multiobjective programming, DEA & {$[27]$} \\
Multiobjective programming and ANP & {$[20]$} \\
Neuronal network y DEA & {$[22]$} \\
Fuzzy multiobjective & {$[28]$} \\
Fuzy TOPSIS and MCGP & {$[4]$} \\
Multiobjective model and AHP & {$[7]$} \\
QFD and linear programming & {$[5]$} \\
QFD and DEA & {$[11]$} \\
\hline
\end{tabular}

Table 2. Fuzzy AHP scale [25].

\begin{tabular}{ccc}
\hline $\begin{array}{c}\text { Linguistic scale for relative } \\
\text { importance }\end{array}$ & Triangular fuzzy scale & $\begin{array}{c}\text { Reciprocal of } \\
\text { triangular fuzzy scale }\end{array}$ \\
\hline Exactly the same & $(1,1,1)$ & $(1,1,1)$ \\
Same importance & $(1 / 2,1,3 / 2)$ & $(2 / 3,1,2)$ \\
Slightly important & $(1,3 / 2,2)$ & $(1 / 2,2 / 3,1)$ \\
Serious importance & $(3 / 2,2,5 / 2)$ & $(2 / 5,1 / 2,2 / 3)$ \\
More serious importance & $(2,5 / 2,3)$ & $(1 / 3,2 / 5,1 / 2)$ \\
Absolutely importance & $(5 / 2,3,7 / 2)$ & $(2 / 7,1 / 3,2 / 5)$ \\
\hline
\end{tabular}

This company is one of the largest and the most recognized in the health and beauty business. 
It has customers in 15 countries: USA - El Salvador - Panamá - Guatemala - Perú Ecuador - Costa Rica - México - Venezuela - Chile -Guinea - Aruba - Curazao - Bolivia - Honduras - El Salvador - Nicaragua - República Dominicana.

Its suppliers are locals and internationals. The principal transport mode is terrestrial and they use containers. The problem is to select a 3PL supplier for the container transport.

The volume of containers handled per year in this operation is 93 including both imports and exports.

There are 3 potential suppliers and the criteria are:

- Structural Alignment. It covers aspects related to cultural and technological compatibility of the companies involved. Also considers the interest and commitment to build and maintain an alliance. It includes cultural and technological alignment, experience and confidence.

- Management Aligning. Includes aspects of the affinity between the management styles of the companies involved, including the quality management system and corporate social responsibility programs and risk management (particularly operational risks). In this criterion we consider the quality, social responsibility and strategies alignment.

- $\quad$ Financial skills. Evaluate the aspects of financial position and bargaining power of suppliers. Also considers the evaluation of the costs of the logistics operation.

- Operational skills. Includes the activities and skills of logistics operation. It includes aspects such as delivery, service, flexibility and quality in the distribution. In this feature are implicit elements of risk because of the good performance of these duties, the success of the operation load is derived; therefore, poor performance or failures occurring increase the operational risk for the Company.

Of the four criteria presented, you can see that two of them present the risk.

Table 3 presents the criterion qualification for the potential suppliers. We used a 1 to 5 scale where 1 is associated with poor capacity and 5 is the better value.

Table 3. Supplier ratings for the criterion.

\begin{tabular}{ccccc}
\hline 3PL suppliers & C1 & C2 & C3 & C4 \\
\hline S 1 & 4 & 4.5 & 4 & 3.7 \\
S 2 & 5 & 4.6 & 4 & 4.2 \\
S 3 & 3 & 4.7 & 4 & 4 \\
\hline
\end{tabular}

\section{Results}

Applying the proposed methodology, the following weights to the criteria (Table 4) were obtained. These weights are obtained from the FAHP methodology and judgments made by the experts included in the study. 
Using these values and applying TOPSIS has the following proposal for the 3PL supplier selection. The table 5 presents the wigthed normalized matrix and the positiveideal and negative-ideal solution. And finally in the table 6 the choice selection is showed.

With this approach we have incorporated the subjective elements of the experts and the operational risk is incorporated in the decision too.

Table 4. Criterion weighting (FAHP).

\begin{tabular}{c|c|c|c}
\hline $\mathbf{C 1}$ & $\mathbf{C 2}$ & $\mathbf{C 3}$ & $\mathbf{C 4}$ \\
\hline $20,14 \%$ & $19.27 \%$ & $22.79 \%$ & $37.80 \%$ \\
\hline
\end{tabular}

Table 5. The weighted normalized decision matrix and positive-ideal and negative-ideal solutions.

\begin{tabular}{|c|c|c|c|c|}
\hline 3PL suppliers & C1 & $\mathrm{C} 2$ & C3 & $\mathrm{C} 4$ \\
\hline S 1 & 0.11393 & 0.10882 & 0.13158 & 0.20329 \\
\hline S 2 & 0.14241 & 0.11124 & 0.13158 & 0.23077 \\
\hline S 3 & 0.08545 & 0.11366 & 0.13158 & 0.21978 \\
\hline Positive-ideal solution & 0.14241 & 0.11366 & 0.13158 & 0.23077 \\
\hline Negative-ideal solution & 0.08545 & 0.10882 & 0.13158 & 0.20329 \\
\hline
\end{tabular}

Table 6. Results.

\begin{tabular}{ll}
\hline & Ri \\
\hline S 2 & 0.9683195 \\
S 1 & 0.4086512 \\
S 3 & 0.2659112 \\
\hline
\end{tabular}

\section{Conclusions}

Although there are still many operational risk associated with supply chain elements, this work presents a first approach to joining one of the most important decisions of today's organizations, the selection of their 3PL supplier and the operational risk management. It is important in these decisions involve judgments of experts, because knowledge acquired over his career he is an invaluable element in decision making.

The 3PL supplier selection was made considering all relevant aspects for the company and according with the significance criteria defined by the experts involved in the decision-making process. Operational risk was included in both explicit like supply chain risk management program and implicit into the company's organizational competencies. 


\section{References}

1. Ahuja, B.B.: Vendor Selection in Supply Chain Using Relative. Methodology (2010)

2. Chai, J.: Expert Systems with Applications Application of decision-making techniques in supplier selection : A systematic review of literature. Expert Syst. Appl. Vol. 40, No. 10, pp. 3872-3885 (2013)

3. Chan, F.T.S., Kumar, N.: Global supplier development considering risk factors using fuzzy extended AHP-based approach. Omega, Vol. 35, pp. 417-431 (2007)

4. Daneshvar, B.: Supplier selection using integrated fuzzy TOPSIS and MCGP : a case study. Procedia - Soc. Behav. Sci. Vol. 116, pp. 3957-3970 (2014)

5. Hassanzadeh, S., Razmi, J.: Expert Systems with Applications an integrated fuzzy model for supplier management : A case study of ISP selection and evaluation. Expert Syst. Appl., Vol. 36, No. 4, pp. 8639-8648 (2009)

6. Ho, W.: Strategic logistics outsourcing: An integrated QFD and fuzzy AHP approach. Expert Syst. Appl., Vol. 39, No. 12, pp. 10841-10850 (2012)

7. Hosseininasab, A., Ahmadi, A.: Selecting a supplier portfolio with value, development, and risk consideration. Eur. J. Oper. Res. Vol. 245, No. 1, pp. 146-156 (2015)

8. Işıklar, G.: Application of a hybrid intelligent decision support model in logistics outsourcing. Comput. Oper. Res. Vol. 34, pp. 3701-3714 (2007)

9. Kar, M.B.: A Network-TOPSIS Based Fuzzy Decision Support System for Supplier Selection in Risky Supply Chain. 2014 Seventh Int. Jt. Conf. Comput. Sci. Optim., pp. 288$293(2014)$

10. Karsak, E.E., Dursun, M.: Computers \& Industrial Engineering An integrated fuzzy MCDM approach for supplier evaluation and selection q. Comput. Ind. Eng., Vol. 82, pp. 82-93 (2015)

11. Karsak, E.E., Dursun, M.: Expert Systems with Applications an integrated supplier selection methodology incorporating QFD and DEA with imprecise data. Expert Syst. Appl., Vol. 41, No. 16, pp. 6995-7004 (2014)

12. Kilincci, O., Onal, S.A.: Expert Systems with Applications Fuzzy AHP approach for supplier selection in a washing machine company. Expert Syst. Appl., Vol. 38, No. 8, pp. 9656-9664 (2011)

13. Kull, T.J., Talluri, S.: A Supply Risk Reduction Model Using Integrated Multicriteria Decision Making. IEEE Trans. Eng. Manag., Vol. 55, No. 3, pp. 409-419 (2008)

14. Lee, A.H.I.: A fuzzy supplier selection model with the consideration of benefits, opportunities, costs and risks. Expert Syst. Appl., Vol. 36, No. 2, pp. 2879-2893 (2009)

15. Levary, R.R.: Ranking foreign suppliers based on supply risk. Supply Chain Manag. An Int. J., Vol. 12, pp. 392-394 (2007)

16. Levary, R.R.: Using the analytic hierarchy process to rank foreign suppliers based on supply risks. Comput. Ind. Eng., Vol. 55, 535-542 (2008)

17. Li, F.: A 3PL supplier selection model based on fuzzy sets. Comput. Oper. Res., Vol. 39, No. 8, pp. 1879-1884 (2012)

18. Liu, H.T., Wang, W.K.: An integrated fuzzy approach for provider evaluation and selection in third-party logistics. Expert Syst. Appl., Vol. 36, No. 3, pp. 4387-4398 (2009)

19. Liu, L.: A conceptual framework for vendor selection based on supply chain risk management from a literature. Vol. 1, No. 3, pp. 1-8 (2011)

20. Malmir, R.: A Multi Stage Decision Making Model to Evaluate Suppliers by Using MOLP and ANP in a Strategic Approach. Vol. 2, Vol. 3, pp. 563-577 (2013)

21. Mehralian, G.: Developing a suitable model for supplier selection based on supply chain risks: An empirical study from Iranian pharmaceutical companies. Iran. J. Pharm. Res., Vol. 11, pp. 209-219 (2012) 
22. Nourbakhsh, V.: Considering supply risk for supplier selection using an integrated framework of data envelopment analysis and neural networks. Int. J. Ind. Eng. Comput., Vol. 4, pp. 273-284 (2013)

23. Rajesh, R., Ravi, V.: Supplier selection in resilient supply chains : a grey relational analysis approach. J. Clean. Prod., Vol. 86, pp. 343-359 (2015)

24. Swain, D.P.: Supplier selection in risk consideration: a fuzzy based TOPSIS. Vol. 110, pp. $0-25$

25. Tian, J., Yan, Z.F.: Fuzzy Analytic Hierarchy Process for Risk Assessment to Generalassembling of Satellite. J. Appl. Res. Technol., 11, August, pp. 568-577 (2013)

26. Viswanadham, N., Samvedi, A.: Multi tier supplier selection for a sustainable global supply chain. IEEE Int. Conf. Autom. Sci. Eng., pp. 492-497 (2013)

27. Wu, D., Olson, D.L.: Supply chain risk, simulation, and vendor selection. Int. J. Prod. Econ., Vol. 114, pp. 646-655 (2008)

28. Wu, D.D.: Fuzzy multi-objective programming for supplier selection and risk modeling: A possibility approach. Eur. J. Oper. Res., Vol. 200, No. 3, pp. 774-787 (2010) 